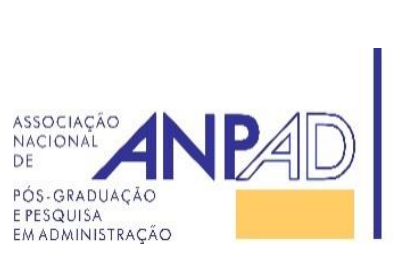

Available online at http://www.anpad.org.br/bar

BAR, Rio de Janeiro, v. 14, n. 2 , art. 6, e160077, 2017

http://dx.doi.org/10.1590/1807-7692bar2017160077

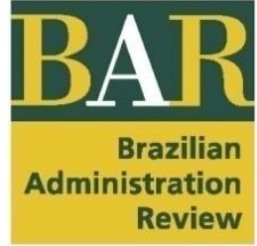

\title{
Ethical Leadership in South Africa and Botswana
}

Priviledge Cheteni ${ }^{1}$ Emmanuel Selemani Shindika ${ }^{2}$

University of Fort Hare ${ }^{1}$ President's Office, Public Service Management ${ }^{2}$

Received 02 August 2016; received in revised form in 22 May 2017 (this paper has been with the authors for two revisions); accepted in 9 June 2017; first published online 28 July 2017. Editor's note. Ivan Beck Ckagnazaroff served as Action Editor for this article. 


\begin{abstract}
This study was conducted to investigate the extent of ethical leadership practices in African public utilities, given the relatively high corruption reported in such institutions, with consequences of seriously constrained development of national economies and significant hindrance to good governance. Our aim was to establish potential benefits from ethical leadership in public sector agencies by analysing ethical leadership characteristics in the public sector from Botswana and South Africa. We measured ethical leadership perceptions utilizing a combination of scales in an attempt to encompass the larger breadth of ethical leadership scales found in the literature in order to determine how employees perceived their managers in terms of being moral people and moral managers. A total of 108 respondents completed questionnaires. Results indicate that there were significant differences between the perceptions of managers' moral conduct. South African leaders were perceived as relatively weaker moral managers as compared to those in Botswana.
\end{abstract}

Key words: Africa; corruption; ethical leadership scale (ELS); managers; moral. 


\section{Introduction}

Ethical leadership has been shown to have considerable benefits for both organisations and businesses. Tanner, Brugger, Schie and Lebherz (2010), Mayer, Kuenzi and Greenbaum (2010) and Piccolo, Greenbaum, Hartog and Folger (2010) demonstrate that it reduces employee absenteeism, misconduct and improves job satisfaction and performance. Rubin, Dierdorff and Brown (2010) also show that managers who are ethical leaders are often perceived to be more suitable to opportunities for promotion. It is therefore an important pillar to successful organisational operations, particularly in countries where relatively higher cases of corruption are recorded (Conrad, 2013). Heres and Lasthuizen (2010) note that the majority of studies on ethical leadership conducted in the US were mainly focused on the business environment, essentially ignoring the societal and organisational factors that may affect notions and manifestations of ethical leadership. Similarly, in Africa, most studies on ethics focus on the private sector, neglecting the public sector, which directly affects citizens.

In 2005, the South African government launched an initiative Batho Pele, meaning people first, which was aimed at improving integrity with public administration through tighter monitoring of officials' performance and compliance with ethical practices. However, Raga and Taylor (2005) argued that such legislation and proliferation of ethical codes of conduct would still be unlikely to put unethical behaviour to an end, and suggested that public officials should be indoctrinated with attitudes and virtues for guiding human conduct, since the public sector presented numerous testing situations due to its diversity. Importantly, integrity training helps officials to gain confidence in providing efficient, ethical, and accountable services.

Although considerable research has been devoted to ethics, significantly less attention has been paid to ethical leadership. Given that, a number of African countries have witnessed huge maladministration of public funds and corruption. This study argues that such behaviour is mainly attributed to leadership. Chief Justice Mogoeng Mogoeng, while addressing delegates at the Serious Social Investing Conference 2016 in South Africa, pointed out that South Africa needs ethical leaders who are not corrupt (Nicolaides, 2016). This view was mainly attributed to the landslide Constitutional ruling in South Africa, were President Zuma was said to have enriched himself with public funds. The South African Constitutional Court ruled that the President failed to uphold, defend and respect the Constitution by using taxpayer's money for his homestead upgrades. On the other hand, Botswana has an established Directorate on Corruption and Economic Crime dealing with cases such as corruption, embezzlement, fraud to name a few. Given the magnitude of this challenge, a study of this nature was a necessity. Consequently, we argue that ethical leadership decadence in public entities is an urgent problem that needs to be addressed instant.

The objective of the study is to assess ethical leadership in African countries, specifically South Africa and Botswana. By comparing them, we aim to identify the shortfalls in ethical leadership, focusing on South African public institutions, which could be addressed to improve the performance of local governance. However, it is noteworthy that ethical violations, corruption, and maladministration are not problems specific to African countries only. For example, the Ethics Resource Center (2008) conducted a national survey in the United States and found that " 57 percent of government employees reported that they had witnessed a violation of ethical standards, policies, or law in their workplace during the previous 12-month period" (p. 1) of which a third went unreported. Kaptein Huberts, Avelino and Lasthuizen (2005) points out that these take the form of misquoting hours worked, unfair treatment of workers, sexual harassment, and violations of privacy.

The rest of the paper is organised as follows: second section provides the literature review; third section provides the methodology that was utilised in the study; fourth section provides the findings and discussion of the results; lastly, final section concludes the study and provides recommendations. 


\section{Literature Review}

\section{Bostwana}

Botswana has relatively strong and well-functioning governance institutions, both public and private. The country has a dual legal system, comprising of customary law and common law, which consists of English and Roman Dutch law, as amended by statutes (United Nations Office on Drugs and Crime [UNODC], 2014). The Constitution that was adopted in 1965 positioned the institutional frameworks that recognize the parliament as a law-making, representative and oversight branch of the State aimed to make sure that the executive branch, under the President as the Head of State, delivers on its mandate (Sebudubudu, 2014). The executive branch in turn has a largely politically neutral civil service to implement all policies, plans and development programmes, including the provision of services to the public in an efficacious manner. Therefore, the Constitution established a non-racial democracy, maintaining freedom of speech, of the press and of association, and affording all citizens equal rights (UNODC, 2012).

Sebudubudu (2014) points out that the public sector in Botswana is prone to many cases of unethical practices, where many cases are of sophisticated white collar crime, and senior private business leaders, politicians and senior government officials who engage in deals involving their own families. The government established well-known authorities to fight unethical and poor governance (Office of the Auditor General, 2008). It Enacted the Directorate on Corruption and Economic Crime (DCEC) Act in September 1994 (Gabriel, 2013). The DCEC is an operationally autonomous law enforcement agency charged with three dedicated directives: to investigate allegations of corruption and economic crime, as well as suspicious transactions, and to share investigative results with the Directorate of Public Prosecutions (DPP) for possible trials. Other mandates are to prevent corruption in the public sector by auditing government and state-owned institutions and lastly to raise awareness of the risks of corruption through public education activities (Sebudubudu, 2014). In 2012, the DCEC received 1,778 cases and 589 classifieds for investigations (Mwamba, 2013). Additionally, nepotism is rampant in the government, involving senior people and many members of the Cabinet (Dube, 2013). However, among Southern African Development Community (SADC) countries, it is a leading country in terms of controlling corruption indicators compared to other countries: Corruption Perception Index 30 out of 177 countries in 2013; World Bank Doing Business ranking 56 out of 189 countries, and United Nations Human Development Index ranking 109 out of 187 in 2014 (these date were obtained from the website http://www.oecd.org/countries/botswana/).

\section{South Africa}

The systems of ethics and governance frameworks in the public sector in the South African context can be well traced and explained fully after the apartheid regime than during apartheid.

A new constitution was developed in 1996 under the platform of non-racialism and equality of all citizens (Constitution of the Republic of South Africa n. 108, 1996). The new constitution tried to address such mythical values of apartheid in the public sector. Section 195 of the Constitution states that public administration must be governed by the democratic values and principles enshrined in the Constitution. Public administration must be broadly representative of the South African people, with employment and personnel management practices based on ability, objectivity, fairness and the need to redress the imbalances of the past to achieve broad representation (Constitution of the Republic of South Africa n. 108, 1996).

In response to section 195 of the Constitution, Rosenbaum (1997) contended that public sectors were reshaped for their new role in the country. Among seven other transformation priorities, public sector ethics, efficacy and accountability were emphasized. Since then, Malunga (2014) asserts that South Africa has responded by implementing a range of legislations and the creation of democratic institutions as vital shields in its quest to build national integrity and fight corruption. This was not easy 
because the heterogeneous and multi-cultural society still experienced a flood of corruption as well as moral relativism and moral contextualization of the apartheid regime (Hilliard \& Ferreira, 2001). To suit the needs of the country, particularly the public sector, several ethics and governance measures were adopted related to international and national frameworks (Malunga, 2014). Such measures (policies, legislative and regulatory frameworks) consist of the key institutions, sectors, laws, practices and specific mechanisms that together contribute to enhancing good governance.

These include the following: The Public Service Commission (PSC), an institution established in terms of Chapter 10 of the 1996 Constitution with a mandate of promoting a high standard of professional ethics in the public sector and to investigate, monitor, and evaluate the organisation, administration, and personnel practices of public service (PSC, 2010). In addition, the institution focuses on performing a vital role in the development of the Code of Conduct for the Public Sector that forms the basis of the public sector's integrity framework as it sets values for ethical conduct across the country. Another institution is the Public Protector, which is a national Ombudsman established under section 181 of the Constitution which forms part of the national integrity framework, and has two mandate dimensions (Department of Public Service and Administration [DPSA], 2003; Disoloane, 2012; Malunga, 2014). The Public Protector's role in anticorruption is also recognized in the key anticorruption statutes, including the Prevention and Combating of Corruption Act, the Protected Disclosures Act and the Public Finance Management Act. For example, the Prevention and Combating of Corrupt Activities Act specifically gives the Public Protector the authority to investigate any improper or dishonest act, or omission or offences referred to in the Act, with respect to public money (Madonsela, 2010; Malunga, 2014).

\section{Ethical leadership}

Bok (1990) highlighted that before the Second World War, strengthening and building the character of students through moral education was considered an important aspect in one's intellectual life, but the idea had faded in public administration in a society that increasingly encouraged tolerance rather than commitment to a single set of moral guidelines. Menzel (1997) conducted a survey with 78 members of National Association of Schools of Public Affairs and Administration (NASPAA) to explore perceptions on the impact that undertaking a course in ethics had on public administration students later in their careers. The survey suggested that education in ethics had helped public officials deal with challenges of moral issues at work. More importantly, ethics educators "developed an awareness of ethical issues and cultivated an attitude of moral obligation and personal responsibility in pursuing a career in the public service" (Menzel, 1997, p. 520).

As a potential solution to corruption and the lack of moral values in organisations, a comprehensively discussed concept is ethical leadership. Brown, Treviño and Harrison (2005) define ethical leadership as "the demonstration of normatively appropriate conduct through personal actions and interpersonal relationships, and the promotion of such conduct to followers through two-way communication, reinforcement, and decision making" (p. 118). Commentators on ethical leadership that include Brown et al. (2005), De Hoogh and Den Hartog (2008), conceptualize ethical leadership as a set of behaviours or a separate leadership style in itself rather than focusing only on the ethical components of other leadership styles. Kanungo (2001) and Turner, Barling, Epitropaki, Butcher and Milner (2002) discuss ethical leadership as a pressure exerted on officials to choose between the good and the bad, referred to as altruistic and egoistic motives. Leaders can improve organisational performance by influencing the performance of their subordinates through behaviours, such as expressing a convincing vision, leading by example, and the use of symbols, rituals, ceremonies, and stories (Yukl, 2008). Brown et al. (2005) described ethical leaders as models of ethical conduct who become the targets of identification and emulation for followers.

For leaders to be perceived as ethical leaders and to influence ethics-related outcomes, subordinates must perceive them as attractive, credible, and legitimate (Brown, Treviño, \& Harrison, 2005). This is achieved through engaging in behaviour that is clearly viewed as appropriate, such as openness and honesty and motivated by altruism (e.g., treating employees fairly and considerately). 
Ethical leaders must also gain followers' attention to the ethics message by engaging in explicit ethicsrelated communication and by using reinforcement to support the ethics message. They make organisational decisions carefully aligned with ethical values and consider that the right decision is always that which falls on the ethics side. Additionally, they constantly highlight to workers the importance and contents of ethical behaviour, hence making it clear for employees that upholding ethics is a vital component of their work. Social learning theory specifies, "Individuals are more likely to pay attention to the behaviour of credible and high status models that have control over valued rewards" (Suff, Reilly, \& Cox, 2007, p. 2), and so in administration, leaders are viewed as role models owing to their organisational rank and managerial powers (Suff et al., 2007).

However, Yukl (2008) noted that at times the side effects of leader behaviour on one performance determinant might have adverse consequences on another. For instance, an applicable case in public administration is when workers are empowered to make work related decisions, they may become more motivated and gain more satisfaction from their jobs, but if employees become fixated on successful customer service, the number of customers served may decrease, resulting in lower efficiency.

According to Brown et al. (2005), most ethical leadership discussions are associated with transformational and charismatic leadership paradigms. Leaders who were transforming their behaviours were more likely to motivate subordinates to follow by engaging in moral practice systems. Hence, the assumption is that followers view the leader as a role model. Kelman (1958) asserted that the change in attitudes emanating from social influence occurs at three different levels: compliance, identification, and internalisation. Compliance is when an individual accepts influence essentially to avoid punishment or to gain specific rewards, regardless of their beliefs. In the context of public administration, it is worthwhile to note that this motive based on gains may be overlooked by the potential gains an individual would expect from conducting unethical behaviour or corruption. Kanungo and Mendonca (1996) however argued that the strategy was unethical in itself, as it coerced followers and undermined their dignity, which could result in self-denial or loss of self-esteem for the benefit of the leader. Identification was described as when one accepts influence due to wanting to establish a selfdefining relationship to another person or group. Therefore, again, the individual is not concerned with their personal beliefs towards the adopted morals or behaviour. Lastly, in internalisation, the individual's personal values align with the new behaviour or believe that it is a useful solution to a problem. A study by Turner et al. (2002) supported the notion of successful transformation influence on ethical conduct from superiors. It was however found unrelated to transactional leadership, which is influence based on contingent reinforcement, a view contrasting Kelman's (1958) propositions. Transactional leadership is a style of leadership in which leaders promote follower compliance through punishments and rewards.

\section{Ethical climate}

Reidenbach and Robin (1990) theorized that individuals used numerous philosophical viewpoints of ethics and morals, which included justice, relativism, egoism, utilitarianism, and deontology, when making ethical judgments. Ethical judgments were distinguished to emanate from three perspectives: moral equity, contractualism, and relativistic judgments. A decision made in the moral equity perspective is motivated by one's assessment of the action in terms of its moral righteousness, justice, and fairness. Contractualism emphases on one's understood obligations on their job. The relativistic perspective considers the appropriateness of a decision centred on the relative moral standards of the organisation.

Mayer, Kuenzi, Greenbaum, Bardes and Salvador (2009) discuss the concept of a work place's ethical climate facilitating the association of ethical leadership and employee delinquency. They define ethical climate as "the holistic impression that individuals have regarding ethical policies, practices, and procedures within a unit or organization" (p. 8). To achieve an ethical environment at a work place, ethical leaders actively establish practices that strictly adhere to conserving ethical values. Ethical leaders demonstrate to employees that ethical standards are a priority, even when they have to be upheld at the expense of the organisation's immediate objectives. In principle, by exemplary behaviour, ethical leaders build an environment in which employees consider ethical values as an important part of their work. 
Stringer (2002) further supports the notion by observing that most leadership research findings show that leaders' behaviour is the most influential aspect determining the organisational climate. More interestingly, Schminke, Ambrose and Neubaum (2005) empirically establish that the leader's moral development and the consistency between the leader's moral development and actions are strong determinants of an organisation's ethical climate. This followed extensive conceptual work by Dickson, Smith, Grojean and Ehrhart (2001); Logsdon and Corzine (1999); Logsdon and Yuthas (1997); Sims (2000); Sims and Brinkman (2002); and Trevino, Hartman and Brown (2000) which posed that leaders' personal characteristics, such as moral development, had substantial influence on an organisations' ethical climate.

Sims and Brinkmann (2002) demonstrate that leaders shape and reinforce an ethical or unethical organisational climate by what they consider to be priorities, their solutions to predicaments, behaviour in the organisation, how they behave, how they allot rewards, and their principles in recruitment and dismissal of employees. Leadership that is consistent in their focus and priorities pass on a strong message to employees about the values important in an institution. In contrast, inconsistent behaviour influences subordinates to relax commitment to the rules and values. Trevino and Nelson (1999) also pose that when leaders concentrate on maximising organisational short-term financial gains, employees adopt similar practices at the expense of values. As an additional benefit to cultivating a culture of high ethical values, Obalola, Aduloju and Olowokudejo's (2012) and Valentine, Godkin and Lucero (2002) found that employees were more likely to be strongly committed to an organisation that promoted and upheld ethical values.

\section{Other variables of the ethical environment}

Various variables (gender, age, marital status, etc.) are suggested in ethics literature to determine the ethical culture within organisations. However, Pierce and Sweeney (2010) note that there are contradictory findings in most research of studies investigating the effect of demographic variables on ethical decision-making. Firstly, Peterson (2002) found that age was a significant variable for ethical behaviour. Mature employees seemed to possess higher ethical values compared to the younger workers and showed stronger resistance to external influence from sources, such as their personal circumstances or from other individuals.

Regarding the gender variable, Kracher, Chatterjee and Lundquist (2002), and Peterson (2002) found that commitment to ethical values differed remarkably within gender. Betz, O'Connell and Shepard (1989) found that men were twice as likely and more willing to engage in unethical behaviour when it comes to work-related values and willingness to engage in unethical behaviour, as compared to women. Prior research by Ruegger and King (1992), Longenecker, McKinney and Moore (1989) and Weeks, Moore, McKinney and Longenecker (1999) supported that women tend to hold a stricter stance on maintaining ethical considerations than men.

Furthermore, Peterson, Rhoads and Vaught (2001) found that gender and age were predictors of ethical beliefs in Democratic Republic of Congo (DRC). However, research on ethical culture, job retention and performance (known as work engagement, job satisfaction, organisational commitment and OCB) in the context of the Democratic Republic of Congo (DRC) has not yet been empirically conducted. Therefore, this study suggests that gender, age, educational level and length of service will moderate the relationship between ethical climate and job retention and performance constructs. In addition to gender, Pierce and Sweeney (2010) found that firm size had significant association with ethical decision-making.

\section{Frameworks for measuring ethical leadership}

Prior to 2007, Brown et al. (2005); Ciulla (2004); Iles and Macaulay (2007) reported that the concept of ethical leadership remained largely unexplored, suggesting research opportunities for new discoveries and leaders' opportunities to improve their effectiveness. Since then, modelling a measure of ethical leadership has received considerable attention from researchers. One of the most influential 
was the Ethical Leadership Scale (ELS). Brown et al. (2005) pose that the instrument they developed to measure ethical leadership (ELS) "is consistent with the proposed theoretical perspective and captures the breadth of the ethical leadership construct" (p. 130). Item generation was developed from a process that initially started with a pool of 48 items based on previous theorizing and research and generated categories similar to those found by Treviño, Brown and Hartman (2003).

According to the ELS model, ethical leadership develops from fundamental features and conduct, which include demonstrating integrity and high ethical standards, considerate and fair treatment of employees, and holding employees accountable for ethical conduct. Additionally, they pose that their tool is highly reliable, and statistically predicts relationships with variables in the sphere of ethical leadership. Moreover, descriptions of ethical leadership characteristics from different subordinates of the same superior were found to be matching when utilising the ELS, suggesting its reliability. Another advantage pointed out was that given the diverse characteristics associated with ethical leadership, the ELS is a convenient summarised model that is easy to apply in research. Despite the wide perception that ethical leadership is a multi-faceted concept, Kalshoven, Den Hartog and De Hoogh (2011) observed that until recently, research had not measured multiple ethical leader behaviours. The author illustrated seven ethical leader behaviours: fairness, people orientation, role clarification, ethical guidance, environment orientation, power sharing and integrity.

However, Yukl, Mahsud, Hassan and Prussia (2013) pose that prior theory and research on ethical leadership has created substantial conceptual confusion about the scope of the ethical leadership construct domain and the appropriate way to measure it. They therefore comprehensively review recent models in an attempt to develop a questionnaire that addresses the identified weaknesses. Yukl et al. (2013) note that the ELS exclude important traits of ethical leadership including honest communication, conduct consistent with ethical values, impartial distribution of tasks amongst employees and rewards. They also argue that discriminant validity testing for honesty was inconsistent because (unlike the ELS items) honesty was only measured with two negatively worded items and not positively worded items. With Craig and Gustafson's (1998) Perceived Leader Integrity Scale, they note "the major limitation of the PLIS is the lack of positively worded items, because absence of unethical behaviour does not necessarily imply a high level of ethical behaviour" (p. 39). Regarding the Ethical Leadership Work Questionnaire by De Hoogh and Den Hartog (2008, p. 300), they point out that "limitations of the questionnaire include the use of items with multiple components and vague wording and mixing of early positive and negatively worded items in a way that can confuse respondents and complicate data analyses". Walumbwa, Avolio, Gardner, Wernsing and Peterson's (2008) Authentic Leadership Questionnaire and Servant Leadership Questionnaires Barbuto and Wheeler (2006) were found not to appear to describe essential aspects of ethical leadership. Yukl et al. (2013) argue that the interpersonal skills and wisdom qualities described in other servant leadership models could enhance problem solving but do not necessarily result in decisions that are ethical.

Yukl et al. (2013) summarize the most relevant principles of ethical leadership as:

(a) honesty and integrity (including consistency of actions with espoused values), (b) behaviour intended to communicate or enforce ethical standards, (c) fairness in decisions and the distribution of rewards (no favouritism or use of rewards to motivate improper behaviour), and (d) behaviour that shows kindness, compassion, and concern for the needs and feelings of others (rather than attempts to manipulate, abuse, and exploit others for personal gain) (p. 40).

They designed an ethical leadership questionnaire (ELQ), and note that compared to previous models, the ELQ has distinct advantages in that it includes the fundamental forms of ethical conduct, "it is not confounded by other leader behaviours, and it is short and easy to use" (Yukl et al., 2013, p. 46).

Finally, (to the scope of this study) Conrad (2013) developed the Corporate Culture Ethical Leadership Scale (CCELS), which particularly addressed problems associated with previous ethics questionnaires. Highlights include more unambiguous and in-depth questions than the ELS items, to address the criticism that many of the ELS items are abstract and expect respondents to be relatively competent about what characterizes ethical leadership (Tanner, Brugger, Schie, \& Lebherz, 2010). 
Furthermore, the CCELS advances the question of misuse of power - a theme commonly associated with unethical leadership, and so appearing to eliminate ELS' limitation of excluding important aspects of leadership as discussed before (Conrad, 2013).

\section{Methodology}

This study used a quantitative methods approach. The investigation merited a quantitative approach because quantitative data helped provide a deeper understanding of the issue under study. Quantifying leadership traits using a scale helped provide a better understanding of their leadership. This was made possible by simply comparing the response to the scale.

\section{Sample}

The sample comprised of 64 South African employees in public institutions, which included Provincial and District Municipalities. In addition, 44 public service workers from Botswana were included in the survey, to facilitate comparisons. In total, this meant there were 108 survey participants. The higher South African sample was capacitated by the researcher's study area, yet in Botswana limited financial budget and time were hindrances to collecting data from more respondents. Pseudonyms were given to the supervisors to track their ratings and to facilitate analysis of age, work experience and gender differences.

The respondents in South Africa were from the Public Service Commission (15), Department of Public Works (22) and Department of Public Enterprises (27). Yet, in Botswana, the respondents were from the Ministry of Local Government. In both countries, respondents from the selected government departments were chosen based on their proximity to public service delivery were they practise leadership on a day-to-day basis compared to other departments. In both countries, all respondents were in management positions, leading people in their various capacities as government employees. All respondents were purposively sampled, since special attention was on public service employees who were in leadership positions (managers and directors).

\section{Procedures}

Semi structured questionnaires were utilised to solicit information from participants from the two countries. Contact was first made through the organisations and then emails were sent to candidates requesting their willingness to participate in the survey. Finally, questionnaires were delivered to respondents and requested to be returned within a week, in an effort of avoiding pressuring respondents and simultaneously meeting the deadline times afforded to conduct fieldwork surveys. The data was collected in 2013-2014 by the researcher in both countries with the cooperation of the personal assistants or administrators of the senior managers or directors. Descriptive statistics were utilised to analyse the gathered data.

\section{Measures}

To maintain continuity with earlier research, items included in the ethical leadership measuring questionnaire (contained in Appendix) were based principally on recent models of measuring ethical leadership, namely, Brown et al.'s (2005) Ethical Leadership Scale (ELS), the seven ethical leader behaviours developed by Kalshoven et al. (2011), and a new measure - Conrad's (2013) corporate culture scale. While there are close similarities amongst the measures used within each model, each claims and demonstrates development from the previous, and hence possesses advantages from the previous model Section Frameworks for measuring ethical leadership discussed in detail. According to Michie and Gooty (2005), Van Wart (2005) and Treviño et al. (2003), ethical leaders (additionally) have genuine interest in others' well-being and the broader common good. Therefore, question 13 was 
included to measure this aspect. The models using employee perceptions were preferred, following selfperception reporting research that suggested that leaders would most probably biasedly disassociate themselves with negative behaviour and rate themselves favourably (Ashford, 1989; Atwater, Ostroff, Yammarino, \& Fleenor, 1998; Brown et al., 2005). All items were measured on 5-point Likert scales ranging from 1 (strongly disagree) to 5 (strongly agree). As Conrad (2013) suggests, the scale also includes Q11 - a question that taps into one of the most common unethical leadership themes across cultures: the misuse of power (Resick et al., 2011), which partially addresses the ELS limitation of not including some relevant aspects of ethical leadership (Yukl, Mahsud, Hassan, \& Prussia, 2011). T-tests were utilised to test the significances of mean differences in comparing morality perceptions of managers in South Africa and Botswana.

\section{Findings}

The demographic findings of the study revealed that the sample $(N=64)$ in South Africa was dominated by males $(63 \%)$ who were between the ages of $40-65$ years. In terms of qualifications, a majority $(71 \%)$ of the respondents held at least a postgraduate degree. Yet, in terms of experience in their current position, the majority had 10-15 years of experience. In Botswana, 58\% of the respondents $(N=44)$ were males. On average, the most dominant age group was between 34-45 years, and in terms of experience, the majority had between 5-10 years of experience. Likewise, most held a degree or diploma. There were striking differences between the two countries, mainly because of the public services developmental resources available for employees. South Africa has one of the most efficient public service sectors in Africa, while Botswana is a leading country in terms of less corruption in public service (United Nations Public Administration and Development Management [UNPAN], 2013).

Table 1 shows the utilised ethical leadership items in the order of their average scores from South Africa, and (not in order) Botswana.

Table 1

\section{The Combined Leadership Scale Mean}

\begin{tabular}{llll}
\hline ITEM & MY DIRECT SUPERVISOR/MANAGER: & $\begin{array}{l}\text { South African } \\
\text { Mean }\end{array}$ & $\begin{array}{l}\text { Botswana } \\
\text { Mean }\end{array}$ \\
\hline Q1 & Is fair and unbiased when assigning tasks to members & 4.55 & 4.31 \\
\hline Q2 & Communicates clear ethical standards for members & 4.43 & 4.11 \\
\hline Q12 & $\begin{array}{l}\text { Is fair and objective when evaluating member performance and } \\
\text { providing rewards }\end{array}$ & 4.41 & 4.21 \\
\hline Q5 & Sets an example of dedication and self-sacrifice for the organization & 4.21 & 4.43 \\
\hline Q4 & Opposes the use of unethical practices to increase performance & 4.12 & 4.11 \\
\hline Q7 & Shows a strong concern for ethical and moral values & 3.89 & 4.31 \\
\hline Q9 & Regards honesty and integrity as important personal values & 3.81 & 4.43. \\
\hline Q8 & Is concerned about the long-term, not just the short-term. & 3.71 & 4.21 \\
\hline Q13 & Puts the needs of others above his/her own self-interest. & 3.71 & 4.11 \\
\hline Q14 & Acknowledges mistakes and takes responsibility for them. & 3.65 & 3.85 \\
\hline Q3 & Holds members accountable for using ethical practices in their work & 3.65 & 3.91 \\
\hline
\end{tabular}

Continues 
Table 1 (continued)

\begin{tabular}{llll}
\hline ITEM & MY DIRECT SUPERVISOR/MANAGER: & $\begin{array}{l}\text { South African } \\
\text { Mean }\end{array}$ & $\begin{array}{l}\text { Botswana } \\
\text { Mean }\end{array}$ \\
\hline Q11 & $\begin{array}{l}\text { Uses their power wisely - they use power to help most people and } \\
\text { not just to benefit themselves and/or their close people. }\end{array}$ & 3.59 & 4.41 \\
\hline Q6 & $\begin{array}{l}\text { Is open to communications and a good listener - they say what } \\
\text { they think and people feel comfortable talking with them (even } \\
\text { about bad news) }\end{array}$ & 3.48 & 4.21 \\
\hline Q10 & Can be trusted to carry out promises and commitments & 3.21 & 4.43 \\
\hline Q15 & Is honest and can be trusted to tell the truth & 3.18 & 3.91 \\
\hline Q16 & Insists on doing what is fair and ethical even when it is not easy & 3.11 & 3.74 \\
\hline Q17 & $\begin{array}{l}\text { Keeps their actions consistent with their stated values (walks the } \\
\text { talk) }\end{array}$ & 2.77 & 3.63 \\
\hline Q18 & Sets an example of ethical behaviour in their decisions and actions & 2.71 & 3.50 \\
\hline
\end{tabular}

The aggregate means for perceived morality amongst South African managers was 3.68 while for Botswana it was 4.34. An unpaired-comparison t-test yielded a p-value of 0.0132 , indicating that the aggregate mean differences of moral conduct items between South African and Botswana managers were statistically significant. However, further analysis showed that the means for perceived moral actions (assessed by items: Is fair and unbiased when assigning tasks to members, and Communicates clear ethical standards for members) were relatively higher for South Africa (4.49) compared to Botswana (4.21), although not statistically significant. Means for perceived traits (significant) and behaviours (significant) of ethical morality were higher for Botswana compared to South Africa.

Ayeni (2002) seemed to support the perception of higher moral traits and behaviours, by pointing out that Botswana's record of performance has been made possible largely by the quality of its public administration, the calibre of people employed in it, and the appropriateness of the institutions and processes put in place. Alexander and Kaboyakgosi (2012) also conclude their study by mentioning that in Botswana, services are provided because it is the right thing to do, not because they are recognised as rights to be progressively realised. This was further reflected through a survey conducted in Botswana in 2008, where respondents were asked: How well or badly would you say the current government is handling or managing the economy, or haven't you heard enough to say? More than three quarters $(76 \%)$ of respondents rated the government as doing fairly well or very well (Alexander \& Kaboyakgosi 2012).

The effort towards ethical leadership actions in South Africa, shown by a higher mean, may be a reflection of government policies and awareness campaigns that have been initiated to fight corruption and initiate integrity (PSC, 2005). However, this is not enough to combat the ills, since the data suggests that managers have only positively responded by being involved in physical action that promotes or supports ethical leadership. Other more important aspects of ethical leadership, involving attitudes and traits, that are more likely to influence employees in upholding moral values, still seem to lag behind. Since awareness of the moral values seems evident (by communicating or displaying appropriate ethical conduct in the presence of employees), the problem may be emanating from a lack of accountability for top managers. This is further supported by the fact that the four lowest ranked items seem to point to negative attitudes, not ignorance, towards ethical leadership. These were: (My supervisor/ Manager) Can be trusted to carry out promises and commitments; Is honest and can be trusted to tell the truth; Insists on doing what is fair and ethical even when it is not easy; Keeps their actions consistent with their stated values (walks the talk); Sets an example of ethical behaviour in their decisions and actions. Enforcement of ethical principles at the top level of managers is therefore a possible problem. 
The findings of this study are consistent to Rasheed's (2014) observations that the lack of accountability, unethical behaviour and corrupt practices have become so pervasive, and even institutionalised norms of behaviour in Africa, to the extent that one may conveniently speak of a crisis of ethics in African public services. While one could single out a few countries, such as Namibia and Botswana, in which tolerable levels of corruption exists, unfortunately the opposite is true in the majority of African countries. The success of Botswana has been substantiated by its commitment to good governance and opening an Ombudsman office in 1997. Furthermore, the United Nations High Commissioner for Refugees (2014) reports that that the country does not have special legislation that addresses commercial disputes and that it still has to appoint an independent regulatory body, which hints on the level of moral values in Botswana.

\section{Conclusion and Recommendations}

Having identified the source of hindrances to ethical leadership in Botswana and South African public utilities using the survey, we recommend that efforts should firstly be made to make it easier for subordinates to report ethical misconduct. The item Is open to communications and a good listener - they say what they think and people feel comfortable talking with them (even about bad news) was ranked relatively lowly (twelfth out of eighteen). For example, employees should be encouraged to use anonymous reports and even directly communicate with approachable managers to disclose misconduct. Similarly, Yukl (2013) poses that the institution's environment should be designed to encourage open and honest communication of ethical problems, taking action to deal with any problems and protecting the messenger from negative repercussions. Additionally, managers can model ethical behaviour, recognize good examples of ethical conduct, and hold people accountable for unethical actions (Dineen, Lewicki, \& Tomlinson, 2006). Another potential solution to problems of ethical conduct could be providing ethics training to employees, to indoctrinate ethical behaviour and to help improve understanding of the importance of ethical leadership and values and the use of ethics as a criterion in decisions involving hiring and promotion (West \& Berman, 2004). The results of this study contribute to the current discourse on ethical leadership, and how it affects service delivery in some African countries.

Previous research indicates differences in ethical judgements (Cohen, Pant, \& Sharp, 1995; Jackson, 2000) and ethical perceptions (Arnold, Bernardi, Neidermeyer, \& Schmee, 2007; Smith \& Hume, 2005) between countries. South Africa and Botswana are diverse countries with differing cultures. Possible differences between South Africa and Botswana on what ethics entail may have negative effects on the findings (and comparisons) in this study. Therefore, we suggest that as an area of further research, the definitions and characteristics of ethical leaderships in South Africa and amongst other African nations be investigated as has been with countries such as Ireland, China, U.S (Resick et al., 2011) and Kazakhstan (Conrad, 2013). Additionally, the study did not account for other effects such as possible effects of demographic aspects that may be involved in ethical leadership or conduct. For example, Browning and Zabriskie (1983), Murphy, Smith and Daley (1992) and Weber (1990) found that organisation size tends to influence ethical decision-making and that as organisation size increases, individual ethical beliefs and ethical decision-making behaviour decreases. We propose that in future models, these factors be explored in an African context, which would facilitate knowing where to direct effort to help develop ethical leadership and conduct. The reason being that culture and beliefs play a significant role in leadership, especially in the sub-Saharan Africa.

\section{References}

Alexander, K., \& Kaboyakgosi, G. (Eds.). (2012). A fine balance: Assessing the quality of governance in Botswana. South Africa: Idasa. 
Arnold, D. F., Bernardi, R. A., Neidermeyer, P. E., \& Schmee, J. (2007). The effect of country and culture on perceptions of appropriate ethical actions prescribed by codes of conduct: A Western European perspective among accountants. Journal of Business Ethics, 70(4), 327-340. http://dx.doi.org/10.1007/s10551-006-9113-6

Ashford, S. J. (1989). Self-assessments in organizations-a literature-review and integrative model. Research in Organizational Behavior, 11, 133-174.

Atwater, L. E., Ostroff, C., Yammarino, F. J., \& Fleenor, J. W. (1998). Self-other agreement: Does it really matter? Personnel Psychology, 51(3), 577-598. https://doi.org/10.1111/j.17446570.1998.tb00252.x

Ayeni, V. (2002). Public sector reform in developing countries: A handbook of commonwealth experience. London: Commonwealth Secretariat.

Barbuto, J. E., \& Wheeler, D. W. (2006). Scale development and construct clarification of servant leadership. Group \& Organization Management, 31(3), 300-326. https://doi.org/10.1177/1059601106287091

Betz, M., O'Connell, L., \& Shepard, J. M. (1989). Gender differences in proclivity for unethical behavior. Journal of Business Ethics, 8(5), 321-324. https://doi.org/10.1007/bf00381722

Bok, D. C. (1990). Universities and the future of America. Durham, NC: Duke University Press.

Brown, M. E., Treviño, L. K., \& Harrison, D. A. (2005). Ethical leadership: A social learning perspective for construct development and testing. Organizational Behavior and Human Decision Processes, 97(2), 117-134. https://doi.org/10.1016/j.obhdp.2005.03.002

Browning, J., \& Zabriskie, N. B. (1983). How ethical are industrial buyers? Industrial Marketing Management, 12(4), 219-224. https://doi.org/10.1016/s0019-8501(83)80001-7

Ciulla, J. B. (2004). Ethics and leadership effectiveness. In J. Antonakis, A. T. Cianciolo, \& R. J. Sternberg (Eds.), The nature of leadership (Chap. 13, pp. 302-327). Thousand Oaks, CA: Sage Publications.

Cohen, J., Pant, L., \& Sharp, D. (1995). An international comparison of moral constructs underlying auditors' ethical judgments. Research on Accounting Ethics, 1, 97-126.

Conrad, A. M. (2013). Ethical leadership in Kazakhstan: An exploratory study. The Journal of ValuesBased Leadership, 6(1), 1-11. Retrieved from http://scholar.valpo.edu/cgi/viewcontent.cgi?article=1072\&context=jvbl

Constitution of the Republic of South Africa n. 108 of 1996. (1996). Retrieved from http://www.gov.za/sites/www.gov.za/files/images/a108-96.pdf

Craig, S. B., \& Gustafson, S. B. (1998). Perceived leader integrity scale: An instrument for assessing employee perceptions of leader integrity. The Leadership Quarterly, 9(2), 127-145. https://doi.org/10.1016/S1048-9843(98)90001-7

De Hoogh, A. H., \& Den Hartog, D. N. (2008). Ethical and despotic leadership, relationships with leader's social responsibility, top management team effectiveness and subordinates' optimism: A multi-method study. The Leadership Quarterly, 19(3), 297-311. https://doi.org/10.1016/j.leaqua.2008.03.002

Department of Public Service and Administration. (2003). Senior management service - public service handbook. Pretoria: Government Printer. Retrieved from http://www.dpsa.gov.za/dpsa2g/documents/sms/publications/smshb2003.pdf 
Dickson, M. W., Smith, D. B., Grojean, M. W., \& Ehrhart, M. (2001). An organizational climate regarding ethics: The outcome of leader values and the practices that reflect them. The Leadership Quarterly, 12(2), 197-217. https://doi.org/10.1016/s1048-9843(01)00069-8

Dineen, B. R., Lewicki, R. J., \& Tomlinson, E. C. (2006). Supervisory guidance and behavioral integrity: Relationships with employee citizenship and deviant behavior. Journal of Applied Psychology, 91(3), 622-635. https://doi.org/10.1037/0021-9010.91.3.622

Disoloane, V. P. P. (2012). Reception of a code of conduct at the Capricorn District Municipality in Limpopo Province (Doctoral dissertation). University of South Africa, Pretoria, South Africa. Retrieved from http://uir.unisa.ac.za/bitstream/handle/10500/5897/dissertation_disoloane_v_.pdf?sequence $=1 \&$ is Allowed $=\mathrm{y}$

Dube, C. (2013, February 21). Galane Gold downplays nepotism allegations. MMegi online. Retrieved from http://www.mmegi.bw/index.php?sid=4\&aid=1227\&dir=2013/february/Thursday 21

Ethics Resource Center. (2008). National government ethics survey: An inside view of public sector ethics. $\quad$ Retrieved from http://www.whistleblowers.org/storage/documents/ethicsresourcecentersuvery.pdf

Gabriel, K. (2013). Managing corruption risks: Botswana builds an anti-graft agency, $1994-2012$. Innovations for Successful Societies, Princeton University. Retrieved from http://successfulsocieties.princeton.edu/sites/successfulsocieties/files/Policy_Note_ID233.pdf

Heres, L., \& Lasthuizen, K. (2010, July). Ethical leadership: A variform universal phenomenon. Proceedings of Annual Conference of the European Group for Organizational Studies, Lisbon, Portugal, 26.

Hilliard, V. G., \& Ferreira, I. W. (2001). Honouring a set of global ethics for South Africa. Journal of Public Administration, 36(2), 87-110.

Iles, P., \& Macaulay, M. (2007). Putting principles into practice: Developing ethical leadership in local government. International Journal of Leadership in Public Services, 3(3), 15-28. https://doi.org/10.1108/17479886200700018

Jackson, T. (2000). Management ethics and corporate policy: A cross-cultural comparison. Journal of Management Studies, 37, 349-369. http://dx.doi.org/10.1111/1467-6486.00184

Kalshoven, K., Den Hartog, D. N., \& De Hoogh, A. H. B. (2011). Ethical leadership at work questionnaire (ELW): Development and validation of a multidimensional measure. The Leadership Quarterly, 22(1), 51-69. https://doi.org/10.1016/j.leaqua.2010.12.007

Kanungo, R. N. (2001). Ethical values of transactional and transformational leaders. Canadian Journal of Administrative Sciences/Revue Canadienne des Sciences de l'Administration, 18(4), 257-265. https://doi.org/10.1111/j.1936-4490.2001.tb00261.x

Kanungo, R. N., \& Mendonca, M. (1996). Ethical dimensions of leadership (Vol. 3). Beverly Hills, CA: Sage Publications. http://dx.doi.org/10.4135/9781452220536

Kaptein, M., Huberts, L., Avelino, S., \& Lasthuizen, K. (2005). Demonstrating ethical leadership by measuring ethics: A survey of US public servants. Public Integrity, 7(4), 299-311.

Kelman, H. C. (1958). Compliance, identification, and internalization: Three processes of attitude change. Journal of Conflict Resolution, 2(1), 51-60. https://doi.org/10.1177/002200275800200106 
Kracher, B., Chatterjee, A., \& Lundquist, A. R. (2002). Factors related to the cognitive moral development of business students and business professionals in India and the United States: Nationality, education, sex and gender. Journal of Business Ethics, 35(4), 255-268. http://dx.doi.org/10.1023/A:1013859404733

Logsdon, J. M., \& Corzine, J. B. (1999). The CEO's psychological characteristics and ethical culture. In M. A. Rahim, R. T. Golembiewski, \& K. D. MacKenzie (Eds.), Current topics in management (Vol. 4, pp. 63-79). Stamford, CT: JAI Press.

Logsdon, J. M., \& Yuthas, K. (1997). Corporate social performance, stakeholder orientation, and organizational moral development. Journal of Business Ethics, 16(12-13), 1213-1216. http://dx.doi.org/10.1023/A:1005741931995

Longenecker, J. G., McKinney, J. A., \& Moore, C. W. (1989). Egoism and independence: Entrepreneurial ethics. Organizational Dynamics, 16(3), 64-72. https://doi.org/10.1016/00902616(88)90037-X

Madonsela, T. N. (2010, January). Corruption and governance challenges: The South African experience. Paper presented at the National Conference on Corruption and Governance Challenges, Lagos, Nigeria, Africa.

Malunga, C. (2014). Animal farm prophecy fulfilled in Africa: A call to a values and systems revolution. Plymout, UK: University Press of America.

Mayer, D. M., Kuenzi, M., Greenbaum, R., Bardes, M., \& Salvador, R. B. (2009). How low does ethical leadership flow? Test of a trickle-down model. Organizational Behavior and Human Decision Processes, 108(1), 1-13. https://doi.org/10.1016/j.obhdp.2008.04.002

Mayer, D. M., Kuenzi, M., \& Greenbaum, R. L. (2010). Examining the link between ethical leadership and employee misconduct: The mediating role of ethical climate [Special Issue]. Journal of Business Ethics, 95, 7-16. http://dx.doi.org/10.1007/s10551-011-0794-0

Menzel, D. C. (1997). Teaching ethics and values: A survey of graduate public affairs and administration programs in the US. PS: Political Science \& Politics, 30(03), 518-524. https://doi.org/10.2307/420135

Michie, S., \& Gooty, J. (2005). Values, emotions, and authenticity: Will the real leader please stand up?. The Leadership Quarterly, 16(3), 441-457. https://doi.org/10.1016/j.leaqua.2005.03.006

Murphy, P. R., Smith, J. E., \& Daley, J. M. (1992). Executive attitudes, organizational size and ethical issues: Perspectives on a service industry. Journal of Business Ethics, 11(1), 11-19. https://doi.org/10.1007/bf00871987

Mwamba, L. (2013). An evaluation of the anti-corruption initiatives in Botswana and their relation to Botswana's development (Master thesis). Development Studies, University of South Africa, Pretoria, South Africa.

Nicolaides, G. (2016, April 12). Chief justice: It's time for change in South Africa. Eyewitness News. Retrieved from http://ewn.co.za/2016/04/12/Chief-Justice-Mogoeng-says-time-for-change-inSA-has-come

Obalola, M., Aduloju, K., \& Olowokudejo, F. (2012). Organizational commitment and corporate ethical values: Exploring the nexus between employees' psychological contract and firms' ethical behaviour in the Nigerian insurance industry. Journal of Management and Sustainability, 2(1), 43-56. https://doi.org/10.5539/jms.v2n1p43

Office of the Auditor General. (2008). The report of the Auditor General on land management at Kgatleng Land Board (Performance Audit Report $\mathrm{N}^{\circ}$ 2). Retrieved from 
http://www.gov.bw/globalassets/oag/performance-audit-

reports/landmanagementbykgatlenglandboard2008.pdf

Peterson, D. K. (2002). The relationship between unethical behavior and the dimensions of the ethical climate questionnaire. Journal of Business Ethics, 41(4), 313-326. http://dx.doi.org/10.1023/A:1021243117958

Peterson, D., Rhoads, A., \& Vaught, B.C. (2001). Ethical beliefs of business professionals: A study of gender, age and external factors. Journal of Business Ethics, 31(3), 225-232. http://dx.doi.org/10.1023/A:1010744927551

Piccolo, R. F., Greenbaum, R., Hartog, D. N. D., \& Folger, R. (2010). The relationship between ethical leadership and core job characteristics. Journal of Organizational Behavior, 31(2-3), 259-278. https://doi.org/10.1002/job.627

Pierce, B., \& Sweeney, B. (2010). The relationship between demographic variables and ethical decision making of trainee accountants. International Journal of Auditing, 14(1), 79-99. http://dx.doi.org/10.1111/j.1099-1123.2009.00404.x

Public Service Commission. (2005, February). State of the public service report - 2005. Department of Public Service. Retrieved from http://www.gov.za/sites/www.gov.za/files/state\%20of\%20the\%20public\%20service\%202005_0.pdf

Public Service Commission. (2010, November/December). Reflections on an ethical public service and society. Retrieved from http://www.psc.gov.za/newsletters/docs/2010/PSC\%20NEWS.pdf

Raga, K., \& Taylor, D. (2005). Impact of accountability and ethics on public service delivery: A South African perspective. Public Manager, 34(2), 22, 244-254.

Rasheed, D. (2014). Following the money: PACs and accountability. PowerPoint presented at the 5th Accountability Conference for West African Public Accounts Committees, Ghana. Retrieved from

http://www.cpahq.org/cpahq/Main/Annual_Conference/Cameroon/PACs_and_Accountability_f or_WAAPAC.aspx

Reidenbach, R. E., \& Robin, D. P. (1990). Toward the development of a multidimensional scale for improving evaluations of business ethics. Journal of Business Ethics, 9(8), 639-653. https://doi.org/10.1007/bf00383391

Resick, C. J., Martin, G. S., Keating, M. A., Dickson, M. W., Kwan, H. K., \& Peng, C. (2011). What ethical leadership means to me: Asian, American, and European perspectives. Journal of Business Ethics, 101(3), 435-457. https://doi.org/10.1007/s10551-010-0730-8

Rosenbaum, P. R. (1997). Signed rank statistics for coherent predictions. Biometrics, 53(2), 556-566. http://dx.doi.org/10.2307/2533957

Rubin, R. S., Dierdorff, E. C., \& Brown, M. E. (2010). Do ethical leaders get ahead? Exploring ethical leadership and promotability. Business Ethics Quarterly, 20(2), 215-236. https://doi.org/10.5840/beq201020216

Ruegger, D., \& King, E. W. (1992). A study of the effect of age and gender upon student business ethics. Journal of Business Ethics, 11(3), 179-186. https://doi.org/10.1007/bf00871965

Schminke, M., Ambrose, M. L., \& Neubaum, D. O. (2005). The effect of leader moral development on ethical climate and employee attitudes. Organizational Behavior and Human Decision Processes, 97(2), 135-151. https://doi.org/10.1016/j.obhdp.2005.03.006 
Sebudubudu, D. (2014). The evolving state of corruption and anti-corruption debates in Botswana: issues in good governance. GIGA German Institute of Global and Area Studies. Retrieved from http://anticorrp.eu/wp-content/uploads/2014/03/Bostwana-Background-Report_final.pdf

Sims, R. R. (2000). Changing an organisations culture under new leadership. Journal of Business Ethics, 25(1), 65-78. http://dx.doi.org/10.1023/A:1006093713658

Sims, R. R., \& Brinkman, J. (2002). Leaders as moral role models: The case of John Gutfreund at Salomon Brothers. Journal of Business Ethics, 35(4), 327-339. https://doi.org/10.1023/a:1013826126058

Smith, A., \& Hume, E. C. (2005). Linking culture and ethics: A comparison of accountants' ethical belief systems in the individualism/collectivism and power distance contexts. Journal of Business Ethics, 62(3), 209-220. https://doi.org/10.1007/s10551-005-4773-1

Stringer, R. A. (2002). Leadership and organizational climate: The cloud chamber effect. Upper Saddle River, NJ: Pearson College Division.

Suff, P., Reilly, P., \& Cox, A. (2007). Paying for performance new trends in performance-related pay the institute for employment studies (HR Network Paper MP78). Brighton, UK, Institute for Employment Studies. Retrieved from http://www.employmentstudies.co.uk/system/files/resources/files/mp78.pdf

Tanner, C., Brügger, A., Schie, S., van, \& Lebherz, C. (2010). Actions speak louder than words. Zeitschrift für Psychologie/Journal of Psychology, 218(4), 225-233. https://doi.org/10.1027/0044-3409/a000032

The Public Service Commission. (2005, July 29). Overview of anti-corruption programmes and strategies in South Africa a look at the past decade, and forward to a common programme of action. $\quad$ Retrieved from http://www.psc.gov.za/speeches/2005/anti_corruption_programmes_strategies.asp

Treviño, L. K., Brown, M., \& Hartman, L. P. (2003). A qualitative investigation of perceived executive ethical leadership: Perceptions from inside and outside the executive suite. Human Relations, 56(1), 5-37. http://dx.doi.org/10.1177/0018726703056001448

Treviño, L. K., Hartman, L. P., \& Brown, M. (2000). Moral person and moral manager: How executives develop a reputation for ethical leadership. California Management Review, 42(4), 128-142. http://dx.doi.org/10.2307/41166057

Trevino, L. K., \& Nelson, K. A. (1999). Managing business ethics: Straight talk about how to do it right (2nd ed.). New York: Wiley.

Turner, N., Barling, J., Epitropaki, O., Butcher, V., \& Milner, C. (2002). Transformational leadership and moral reasoning. Journal of Applied Psychology, 87(2), 304-311. https://doi.org/10.1037//0021-9010.87.2.304

United Nations High Commissioner for Refugees. (2014). UNHCR global trends. Retrieved from http://www.unhcr.org/statistics/country/556725e69/unhcr-global-trends-2014.html

United Nations Office on Drugs and Crime. (2012). Wildlife and forest crime: Analytic toolkit. Retrieved from http://www.cites.org/eng/resources/pub/Wildlife_Crime_Analytic_Toolkit.pdf

United Nations Office on Drugs and Crime. (2014, June). Implementation review group of the United Nations convention against corruption. Retrieved March 15, 2017, from http://www.unodc.org/unodc/en/treaties/CAC/IRG-session5.html 
United Nations Public Administration and Development Management. (2013). Botswana's national egovernment strategy 2011-2016. Retrieved from http://workspace.unpan.org/sites/internet/documents/unpan048687.pdf

Valentine, S., Godkin, L., \& Lucero, M. (2002). Ethical context, organizational commitment, and person-organization fit. Journal of Business Ethics, 41(4), 349-360. http://dx.doi.org/10.1023/A:1021203017316

Van Wart, M. (2005). Dynamics of leadership: Theory and practice. Armonk, NY: ME Sharpe.

Walumbwa, F. O., Avolio, B. J., Gardner, W. L., Wernsing, T. S., \& Peterson, S. J. (2008). Authentic leadership: Development and validation of a theory-based measure. Journal of Management, 34(1), 89-126. http://dx.doi.org/10.1177/0149206307308913

Weber, J. (1990). Managers' moral reasoning: Assessing their responses to three moral dilemmas. Human Relations, 43(7), 687-702. https://doi.org/10.1177/001872679004300705

Weeks, W. A., Moore, C. W., McKinney, J. A., \& Longenecker, J. G. (1999). The effects of gender and career stage on ethical judgment. Journal of Business Ethics, 20(4), 301-313. http://dx.doi.org/10.1023/A:1005955501120

West, J. P., \& Berman, E. M (2004). Ethics training in US cities: Content, pedagogy, and impact. Public Integrity, 6(3), 189-206.

Yukl, G. (2008). How leaders influence organizational effectiveness. The Leadership Quarterly, 19(6), 708-722.

Yukl, G. (2013). Leading in organizations (8th ed.). Boston, MA: Pearson Education.

Yukl, G., Mahsud, R., Hassan, S., \& Prussia, G. E. (2011). An improved measure of ethical leadership. Journal of Leadership and Organizational Studies, 20(10), 38-48. http://dx.doi.org/10.1177/1548051811429352

Yukl, G., Mahsud, R., Hassan, S., \& Prussia, G. E. (2013). An improved measure of ethical leadership. Journal of Leadership \& Organizational Studies, $20(1), \quad 38-48$. https://doi.org/10.1177/1548051811429352

\section{Authors' Profiles}

Priviledge Cheteni

University of Fort Hare, Economic Sciences, King Williams Road, 5700, Alice, Eastern Cape, South Africa. E-mail address: 200909553@ufh.ac.za

Emmanuel Selemani Shindika

Tanzania Public Service College, P. O Box 1051, Mtwara Campus, Tanzania. E-mail address: shindika@yahoo.com 


\section{APPENDIX}

\section{Questionnaire}

\begin{tabular}{|c|c|}
\hline ITEM & MY DIRECT SUPERVISOR/MANAGER: \\
\hline Q1 & Is fair and unbiased when assigning tasks to members \\
\hline Q2 & Communicates clear ethical standards for members. \\
\hline Q3 & Holds members accountable for using ethical practices in their work \\
\hline Q4 & Opposes the use of unethical practices to increase performance \\
\hline Q5 & Sets an example of dedication and self-sacrifice for the organization \\
\hline Q6 & $\begin{array}{l}\text { Is open to communications and a good listener - they say what they think and people feel } \\
\text { comfortable talking with them (even about bad news) }\end{array}$ \\
\hline Q7 & Is concerned about the long-term, not just the short-term. \\
\hline Q8 & Shows a strong concern for ethical and moral values \\
\hline Q9 & Regards honesty and integrity as important personal values \\
\hline Q10 & Can be trusted to carry out promises and commitments \\
\hline Q11 & $\begin{array}{l}\text { Uses their power wisely - they use power to help most people and not just to benefit } \\
\text { themselves and/or their close people. }\end{array}$ \\
\hline Q12 & Is fair and objective when evaluating member performance and providing rewards \\
\hline Q13 & Puts the needs of others above his/her own self-interest \\
\hline Q14 & Acknowledges mistakes and takes responsibility for them \\
\hline Q15 & Is honest and can be trusted to tell the truth \\
\hline Q16 & Insists on doing what is fair and ethical even when it is not easy \\
\hline Q17 & Keeps their actions consistent with their stated values (walks the talk) \\
\hline Q18 & Sets an example of ethical behaviour in their decisions and actions \\
\hline
\end{tabular}

